\title{
Investigation of protein secretion and secretion stress in Ashbya gossypii
}

Tatiana Q Aguiarr ${ }^{1 \dagger}$, Orquídea Ribeiro ${ }^{1,2 \dagger}$, Mikko Arvas $^{3}$, Marilyn G Wiebe ${ }^{3}$, Merja Penttilä ${ }^{3}$ and Lucília Domingues ${ }^{*}$

\begin{abstract}
Background: Ashbya gossypii is a filamentous Saccharomycete used for the industrial production of riboflavin that has been recently explored as a host system for recombinant protein production. To gain insight into the protein secretory pathway of this biotechnologically relevant fungus, we undertook genome-wide analyses to explore its secretome and its transcriptional responses to protein secretion stress.
\end{abstract}

Results: A computational pipeline was used to predict the inventory of proteins putatively secreted by A. gossypii via the general secretory pathway. The proteins actually secreted by this fungus into the supernatants of submerged cultures in minimal and rich medium were mapped by two-dimensional gel electrophoresis, revealing that most of the A. gossypii secreted proteins have an isoelectric point between 4 and 6 , and a molecular mass above $25 \mathrm{kDa}$. These analyses together indicated that 1-4\% of A. gossypii proteins are likely to be secreted, of which less than 33\% are putative hydrolases. Furthermore, transcriptomic analyses carried out in A. gossypii cells under recombinant protein secretion conditions and dithiothreitol-induced secretion stress unexpectedly revealed that a conventional unfolded protein response (UPR) was not activated in any of the conditions, as the expression levels of several well-known UPR target genes (e.g. IRE1, KAR2, HAC1 and PDI1 homologs) remained unaffected. However, several other genes involved in protein unfolding, endoplasmatic reticulum-associated degradation, proteolysis, vesicle trafficking, vacuolar protein sorting, secretion and mRNA degradation were up-regulated by dithiothreitol-induced secretion stress. Conversely, the transcription of several genes encoding secretory proteins, such as components of the glycosylation pathway, was severely repressed by dithiothreitol

Conclusions: This study provides the first insights into the secretion stress response of A. gossypii, as well as a basic understanding of its protein secretion potential, which is more similar to that of yeast than to that of other filamentous fungi. Contrary to what has been widely described for yeast and fungi, a conventional UPR was not observed in A. gossypii, but alternative protein quality control mechanisms enabled it to cope with secretion stress. These data will help provide strategies for improving heterologous protein secretion in A. gossypii.

Keywords: Ashbya gossypii, Proteins secretion, Secretion stress, Secretome, Transcriptome

\section{Background}

The protein secretory pathway is an important area of fungal research, as the secretion of proteins by fungal cells is of major biological and commercial significance. Ashbya gossypii (syn. Eremothecium gossypii), a well known industrial producer of riboflavin [1], is a filamentous fungus that has been recently considered as a host for the production of recombinant proteins [2]. However, its protein

\footnotetext{
*Correspondence: luciliad@deb.uminho.pt

${ }^{\dagger}$ Equal contributors

'CEB - Centre of Biological Engineering, University of Minho, 4710-057 Braga, Portugal

Full list of author information is available at the end of the article
}

secretory pathway and the spectrum of proteins natively secreted by this fungus to the extracellular space remain virtually unexplored. A. gossypii has one of the smallest eukaryotic genomes known [3] and is phylogenetically closer to yeast than to other filamentous fungi [4], sharing a high degree of gene homology and gene order conservation with the budding yeast Saccharomyces cerevisiae [3]. Although efficient protein secretion is generally associated with filamentous growth, the secretion levels of the heterologous proteins endoglucanase I (EGI) and cellobiohydrolase I (CBHI) from Trichoderma reesei in A. gossypii were previously reported to be low [2]. The production of heterologous proteins by fungal species is usually much 
less efficient than the production of native proteins and several steps in the secretory pathway (e.g. translation, translocation, folding, transport and secretion) are potential bottlenecks for heterologous protein production [5-8].

In eukaryotes, newly synthesised proteins are typically targeted for entry into the general secretory pathway by the presence of a $\mathrm{N}$-terminal signal sequence that typically has a length between 15 to 30 amino acids and comprises a central hydrophobic region flanked by hydrophilic $\mathrm{N}$ - and $\mathrm{C}$ - terminal regions [9]. Taking advantage of the characteristics of these signal peptides and other sorting signals, several computational tools have been developed to predict the subcellular location of proteins such as the extracellular space [10-12]. These have been used for the genome-wide prediction of putative fungal secretomes [13]. As the translocation of proteins into the endoplasmatic reticulum (ER) is determined by the secretion signal, the correct processing of signal peptides, together with the proper folding of proteins within the $\mathrm{ER}$, is important in recombinant protein production and secretion $[14,15]$.

The ER serves as the first station of the secretory pathway. Its lumen provides a unique oxidizing environment in which highly active folding machinery, including molecular chaperones and foldases, facilitates and promotes the folding, assembling, modification and maturation of proteins. To ensure that only properly folded proteins move onward through the secretory pathway, the ER also contains stringent quality control mechanisms that retain malfolded (unfolded or misfolded) proteins and ultimately retrotranslocate them into the cytosol for proteasomal degradation through a process called ER-associated degradation (ERAD) (reviewed in [16]). Environmental and physiological demands (e.g. cell differentiation, $\mathrm{pH}$ and temperature, nutrient limitation, expression of heterologous proteins, etc.) can lead to an imbalance between the protein folding load and the protein folding capacity in the ER lumen, resulting in an accumulation of malfolded proteins, i.e. ER stress [17-19]. In response to ER stress, eukaryotic cells have evolved signalling pathways that induce the unfolded protein response (UPR). The UPR activates a gene expression program that helps to restore homeostasis in the ER by enhancing ER protein folding capacity and ERAD, and reducing translation and entry of new proteins into the ER (reviewed in [20,21]).

Cellular responses to the accumulation of malfolded proteins in the ER have been described for yeast, filamentous fungi and higher eukaryotes, and shown to play a significant role in the stress response to production of secreted recombinant proteins [14,22]. The inositolrequiring enzyme 1 (IRE1) gene encodes the protein that controls the most conserved and best understood UPR signalling pathway in lower eukaryotes [23]. Ire1p has a luminal sensing domain coupled to cytosolic kinase and endoribonuclease (RNase) domains [24]. The accumulation of malfolded proteins in the ER lumen leads to the oligomerization of the Ire1p luminal domain and thereby to the activation of its kinase and RNase functions [21].

Upon Ire1p activation, the Ire1p RNase initiates the splicing of a non-conventional intron from HAC1 messenger RNA (mRNA), thus allowing the translation of active Hac1p, a basic-leucine zipper (bZIP) transcription factor that specifically binds to UPR elements (UPREs) in the promoter region of UPR target genes, thereby up-regulating their transcription $[25,26]$. In response to strong ER stress, Ire1p signaling may also cause regulated IRE1-dependent mRNA decay (RIDD) to reduce the ER load by inducing the degradation of mRNAs encoding secretory proteins $[21,27,28]$. Several UPR target genes have been identified, among which are those encoding ER chaperones and protein folding enzymes, ER structural and transport proteins, members of the ERAD machinery and components that mediate autophagy [29-31]. The bZIP transcription factor Gcn4p, a major controller of the amino acid starvation response, has been shown to also play an essential role in the induction of a large subset of these target genes during ER stress, by directly interacting with Hac1p and modulating its activity in an IRE1-independent way [32,33].

The characterization of protein secretory pathway components and of the regulatory range of secretion stress responses in yeast and filamentous fungi has often relied on inducing ER stress with chemical secretion blockers such as the folding inhibitor dithiothreitol (DTT), the glycosylation inhibitor tunicamycin and the protein trafficking inhibitor brefeldin A. In the present study, we analysed the events taking place at the transcription level in A. gossypii under recombinant protein secretion conditions and also under DTT-induced secretion stress, in order to identify bottlenecks that may hamper protein secretion in A. gossypii. Moreover, to explore the native proteins putatively secreted by this fungus, we also analysed its predicted secretome by combining comparative in silico predictions for classically secreted proteins with experimental data derived from two-dimensional (2-D) gel electrophoresis.

\section{Results}

\section{The A. gossypii secretome}

The A. gossypii secretome was predicted from an analysis of its genomic data, using a computational pipeline (see Materials and Methods) to detect known cellular sorting and localization signals in its putative proteins. Of the 4,776 open reading frames (ORFs) annotated in the $A$. gossypii genome, 333 (7\%) were predicted to encode proteins containing a N-terminal signal peptide (Additional file 1: Table A1.1), and thus to enter the general secretory 
pathway. However, only 54 proteins ( $1 \%$ of the $A$. gossypii total proteome) were predicted to be secreted extracellularly by the computational pipeline used (Additional file 1: Table A1.2), the others being targeted to different cellular compartments (Additional file 1: Table A1.1). All of the 54 proteins in the A. gossypii predicted secretome have homologs in closely related Saccharomycotina species, but 7 have no homologs in S. cerevisiae. $67 \%$ were predicted to contain at least one $N$-glycosylation site (Additional file 1: Table A1.2). Enzymes predicted to have hydrolytic activity comprised $33 \%$ of the A. gossypii predicted secretome (Additional file 1: Table A1.2).

\section{Growth and protein secretion by $A$. gossypii}

A. gossypii ATCC 10895 produced $5.7 \pm 0.2$ g/l dry biomass in defined minimal medium (DMM) and $8.1 \pm 0.3 \mathrm{~g} / \mathrm{l}$ in rich medium (AFM) with sucrose as primary carbon source. At the beginning of the stationary phase the supernatant of the culture growing in minimal medium contained a total protein content of $130 \mathrm{mg} / \mathrm{l}$ and that of the culture growing in complex medium contained $218 \mathrm{mg} / \mathrm{l}$.

Sodium dodecyl sulfate polyacrylamide gel electrophoresis (SDS-PAGE) showed 12 distinct protein bands in the culture supernatant of both DMM and AFM cultures, ranging from $7 \mathrm{kDa}$ to $209 \mathrm{kDa}$ (Figure 1B). On 2-D gels, 18 protein spots were visible at higher abundance in the culture supernatants and were common to both DMM and AFM cultures (from a total of 101 spots common to both). Of these, at least 2 were obviously isoforms of other protein spots with identical molecular weight but different isoelectric points (Figures $1 \mathrm{~A}$ and $\mathrm{C}$ ). As shown in Figures $1 \mathrm{~A}$ and $\mathrm{C}$ more protein spots were detected in AFM (182) than in DMM (157) culture supernatants. In addition, the distribution of the protein spots on the 2-D gels indicated that most of the A. gossypii secreted proteins have isoelectric points between 4 and 6 , and molecular weights above $25 \mathrm{kDa}$, although some proteins present only in AFM cultures did have slightly higher isoelectric points (6-8).

\section{Effect of DTT on the A. gossypii growth}

In order to study the effects of secretion stress on $A$. gossypii growth and gene transcription, duplicate bioreactor batch cultivations were carried out with a recombinant EGI producing strain (previously reported to secrete low levels of this heterologous protein [2]), its corresponding empty vector control strain, and the EGI producing strain treated with a well known secretion stress inducer, DTT (Figure 2). As previously described [2], the production of EGI alone did not alter cellular growth. Conversely, the addition of $10 \mathrm{mM}$ final concentration DTT to cultures after $9.5 \mathrm{~h}$ caused a substantial and immediate reduction in the specific growth rate of the $A$. gossypii EGI producing cells (Figure 2). When the same concentration of DTT was added after only $6 \mathrm{~h}$, the $A$. gossypii cells immediately stopped growing (data not shown).

\section{Effect of recombinant protein secretion on the $A$. gossypii transcriptome}

The overall variation in the microarray gene expression profiles between $A$. gossypii cells secreting recombinant EGI and those which did not was very small. LIMMA (i.e. a modified $t$-test) could not detect significant differences between gene expression of the EGI secreting and the empty vector control strains at any time. However, in order to directly study the link between EGI secretion and gene expression, the correlation of each gene's expression to EGI secretion in EGI producing cultivations was calculated. As the correlation analysis included the variation in replicates of single samples (unlike LIMMA), it was expected to be more sensitive than LIMMA. Twentyone genes were found to be differentially expressed

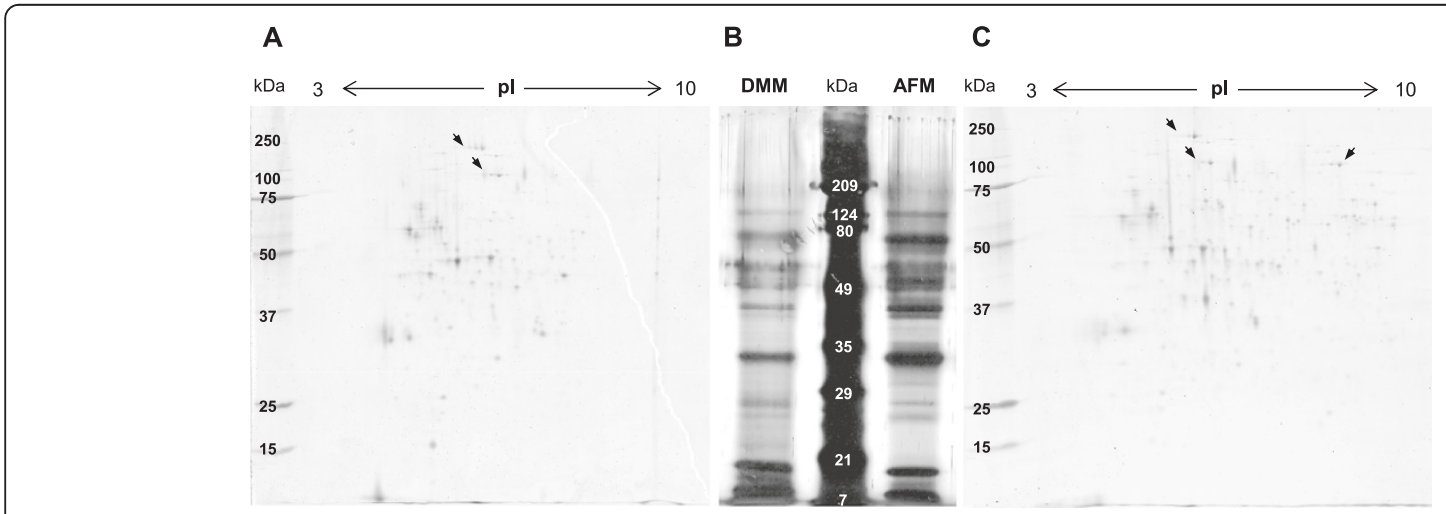

Figure 1 Electrophoretic profiles of the proteins secreted by $\boldsymbol{A}$. gossypii into the culture supernatant. Panels $\mathbf{A}$ and $\mathbf{C}$ show representative 2-D electrophoresis gels of A. gossypii culture supernatants derived from bioreactor batch cultures in minimal (DMM) and rich (AFM) medium, respectively. Pannel $\mathbf{B}$ shows the SDS-PAGE gel of the same supernatants. The arrows indicate spots that are most likely diffent isoforms of the same protein. 


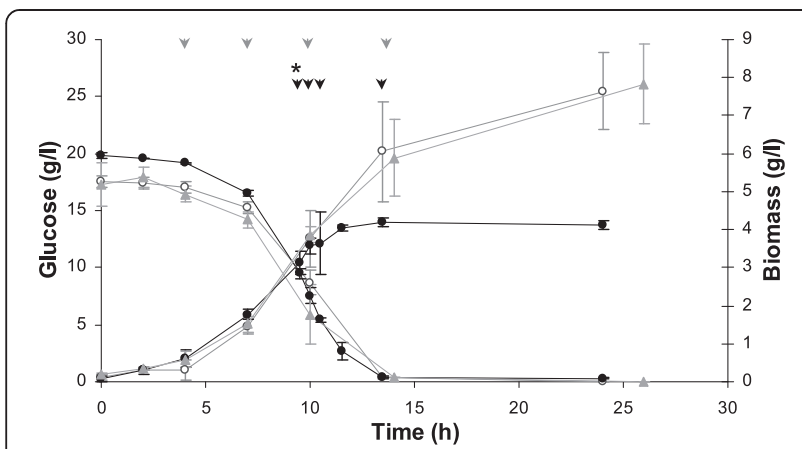

Figure 2 Glucose consumption (solid lines) and growth (dashed lines) of recombinant $A$. gossypii in batch cultures in AFM with $\mathrm{G} 418$ at $\mathrm{pH} 6.0,30^{\circ} \mathrm{C}$ and $500 \mathrm{rpm}$, with $1.0 \mathrm{vvm}$ aeration. (O) EGl producing strain, $(\boldsymbol{\Delta})$ empty vector strain and $(\bullet)$ DTT-stressed EGl producing cells. Values represent the average \pm standard deviation of two independent bioreactor cultures. Grey arrows indicate the sampling times for non-treated cultures and black arrows the sampling points for DTT-treated cultures. *Indicates the time at which DTT was added to EGI producing cultures.

(FDR of 4.4\%) using the correlation approach, of which 16 were up-regulated and 5 down-regulated in the strain secreting recombinant protein (Table 1). Gene ontology (GO) enrichment analyses for this set of genes hinted at translation down-regulation and ion and amino acid transmembrane transport up-regulation having occurred during EGI secretion.

Expression of the eglI gene itself (included in the microarray although not part of the A. gossypii genome) in the EGI producing cells was around 5 fold higher than the background signal of the gene in the nonproducing cells, which contained the empty vector, and approximately 14 fold lower than the expression levels of TEF.

\section{Effect of DTT-induced stress on the A. gossypii transcriptiome}

Upon addition of DTT to cultures of A. gossypii EGI producing cells during logarithmic growth, the gene expression profile changed significantly (Figure 3), as did the growth rate (Figure 2). When comparing the transcript levels of all genes at the time immediately before the addition of DTT ( $9.5 \mathrm{~h}$ after inoculation and defined as time zero for DTT addition) with those at $30 \mathrm{~min}, 1 \mathrm{~h}$ and $4 \mathrm{~h}$ after DTT addition, 128 genes were already up-regulated and 189 down-regulated after $30 \mathrm{~min}$ of exposure to DTT (Figure 3C). The up-regulation of 43 of these genes was sustained up to $4 \mathrm{~h}$ of treatment (Figure 3A), and the same was observed for 140 of the 189 down-regulated genes (Figure 3B). As can be seen from Figure 3C, DTT induced more genes than it repressed. However, down-regulation was greater than up-regulation after $30 \mathrm{~min}$ and $1 \mathrm{~h}$ of DTT treatment, as higher fold changes were observed in the transcript levels of down-regulated than up-regulated genes (Figure 3D).

DTT caused wide-ranging effects on A. gossypii gene expression profiles (Tables 2, 3 and 4). Some of the changes probably correlate with the observed reduction in growth rate (Figure 2). For instance, within $30 \mathrm{~min}$, the transcription of genes involved in filamentous growth (Table 3), glycosylation and lipoprotein biosynthesis (Cluster 1 in Figure 4, Tables 2 and 3), and cell wall biosynthesis was already down-regulated by DTT. A down-regulation of ribosomal protein-encoding genes has been correlated with reductions in growth rate of S. cerevisiae [34,35] and analysis of the co-expression clusters revealed that genes encoding ribosomal proteins were also down-regulated in DTT treated A. gossypii cells compared to the control, particularly after $1 \mathrm{~h}$ of exposure to DTT (Cluster 1 in Figure 4, Table 2).

Treatment of $A$. gossypii cells with DTT led to major repression of the protein glycosylation pathway (in particular of the $\mathrm{N}$-glycosylation pathway) (Tables 2, 3 and Additional file 2). The observed repression was not only at the ER, but also at the Golgi processing level (Additional file 2), indicating that a major accumulation of unglycosylated proteins may have occurred. Genes involved in response to stress, transcription, protein unfolding, proteasome assembly, proteolysis, vesicle trafficking, vacuolar protein sorting, secretion, trehalose biosynthesis and DNA repair were induced by DTT (Clusters 2, 7 and 9 in Figure 4, Tables 2 and 4). However, the expression levels of classical UPR targets such as IRE1, KAR2, HAC1, PDI1 and EUG1 homologs were not altered in A. gossypii cells treated with $10 \mathrm{mM}$ DTT, as confirmed by quantitative PCR (qPCR) (Additional file 3: Figure A3.1). Moreover, the A. gossypii ERO1 and LHS1 homologs, two other classical UPR targets, were transcriptionally down-regulated in A. gossypii (Additional file 2), as was the GCN4 homo$\log$, which has been previously shown to be induced by ER stress in other fungi $[33,36]$.

A search for common regulatory DNA motifs in the promoter region of the DTT-regulated genes identified only 7 motifs that were common within one or more gene clusters (Figure 5), none of which matched known consensus binding sites for the transcriptional factors Hac1p or Gcn4p. Among the common promoter elements found, 4 were similar to known binding sequences for the S. cerevisiae transcription factors Rap1p, Adr1p and Hcm1p. The binding site for Rap1p, a positive transcriptional regulator for multiple growth related genes such as ribosomal protein genes [37], was over-represented in the DTT-induced gene cluster (Figure 5B). The consensus sequence for Adr1p binding was the only motif overrepresented in the A. gossypii DTT down-regulated genes. Adr1p is a carbon source responsive zinc-finger transcription factor that is required for transcription of the 
Table 1 Genes differentially regulated in A. gossypii during the production of recombinant EGI (FDR of 4.4\%)

\begin{tabular}{|c|c|c|c|c|}
\hline & $\begin{array}{l}\text { A. gossypii } \\
\text { gene }\end{array}$ & $\begin{array}{l}\text { S. cerevisiae } \\
\text { homolog(s) }\end{array}$ & Predicted protein function & Biological processes \\
\hline \multirow[t]{16}{*}{ Up-regulated } & AARO30W & CTR1 & High-affinity copper transporter & \multirow[t]{4}{*}{ Amino acid transport } \\
\hline & AAR080W & No homolog & Unknown & \\
\hline & ADL123C & PHO4 & $\begin{array}{l}\text { Transcription factor that activates transcription } \\
\text { cooperatively with Pho2p in response to } \\
\text { phosphate limitation }\end{array}$ & \\
\hline & ADL153W & $R R / 2$ & Subunit of the COP9 signalosome complex & \\
\hline & ADR080W & FRE1 & Ferric reductase and cupric reductase & \multirow{4}{*}{$\begin{array}{l}\text { Iron transmembrane } \\
\text { transport }\end{array}$} \\
\hline & AEL294C & FTR1 & High-affinity iron permease & \\
\hline & AER428W & OM45 & $\begin{array}{l}\text { Major constituent of the mitochondrial } \\
\text { outer membrane }\end{array}$ & \\
\hline & AFL135W & $\begin{array}{l}\text { YMR181C, } \\
\text { YPL229W }\end{array}$ & Unknown & \\
\hline & AFR156W & PUT4 & High-affinity proline permease & \multirow[t]{4}{*}{ Transmembrane transport } \\
\hline & AFR442C & PHO84 & $\begin{array}{l}\text { High-affinity inorganic phosphate transporter } \\
\text { and low-affinity manganese transporter }\end{array}$ & \\
\hline & AFR529W & SUC2 & Invertase & \\
\hline & AFR595W & $\mathrm{MCH}$ & $\begin{array}{l}\text { Protein with similarity to mammalian } \\
\text { monocarboxylate permeases }\end{array}$ & \\
\hline & AFR668W & CAN1, ALP1 & Plasma membrane arginine permease & \multirow[t]{4}{*}{ Ion transport } \\
\hline & AFR739C & No homolog & Unknown & \\
\hline & AGLO97C & $\begin{array}{l}\text { ENA2, ENA5, } \\
\text { ENA1 }\end{array}$ & $\begin{array}{l}\text { P-type ATPase sodium pump, involved } \\
\text { in } \mathrm{Na}^{+} \text {and } \mathrm{Li}^{+} \text {efflux to allow salt tolerance }\end{array}$ & \\
\hline & AGR304W & MTH1, STD1 & $\begin{array}{l}\text { Protein involved in the control of glucose-regulated gene } \\
\text { expression }\end{array}$ & \\
\hline \multirow[t]{5}{*}{ Down-regulated } & $A B L 065 W$ & RPG1 & $\begin{array}{l}\text { Subunit of the core complex of translation } \\
\text { initiation factor } 3 \text { (elF3) }\end{array}$ & Regulation of translation \\
\hline & $A B L 174 C$ & $S S B 2, S S B 1$ & $\begin{array}{l}\text { Cytoplasmic ATPase that is a ribosome-associated } \\
\text { molecular chaperone; may be involved in the } \\
\text { folding of newly-synthesized polypeptide chains; } \\
\text { member of the HSP70 family }\end{array}$ & $\begin{array}{l}\text { Posttranscriptional regulation } \\
\text { of gene expression }\end{array}$ \\
\hline & AELO32W & GCN20 & Positive regulator of the Gcn2 kinase activity & $\begin{array}{l}\text { Regulation of cellular protein } \\
\text { metabolic process }\end{array}$ \\
\hline & AER366W & $F L X 1$ & $\begin{array}{l}\text { Protein required for transport of FAD across the mitochondrial } \\
\text { membrane }\end{array}$ & \multirow[t]{2}{*}{$\begin{array}{l}\text { Regulation of translational } \\
\text { elongation }\end{array}$} \\
\hline & AGR261W & RPS28B, RPS28A & Protein component of the small ribosomal subunit & \\
\hline
\end{tabular}

The corresponding S. cerevisiae homologs are indicated, as well as the predicted functions. The biological processes enriched $(p<0.01)$ in the up- and down-regulated gene clusters are also indicated.

glucose-repressed gene $A D H 2$, of peroxisomal protein genes and of genes required for ethanol, glycerol, and fatty acid utilization [38]. Another had similarity to a Ribosomal RNA Processing Element (RRPE; AAAAATTT), to which the $S$. cerevisiae Stb3p has been demonstrated to bind [39] and that was identified by Gasch et al. [40] as being a common element found in the promoter region of several genes repressed during Environmental Stress Response (rESR). This motif was over-represented in the cluster of $A$. gossypii genes induced by DTT (Figure 5B) and also in the co-expression clusters 3 and 4 (Figure 5A), which are enriched in various functions associated with the RNA metabolism.
The expression of several genes involved in protein folding was significantly induced by DTT after $4 \mathrm{~h}$ of exposure, including JEM1, SIL1, SSA2, STI1, SIS1, FES1, HSP104, HSC82, HSP82, AHA1, MDJ1, HSP78, APJ1 and HSP26 homologs (Additional file 2). Some genes involved in the ERAD (HRD1, USA1, UBX2 and HLJ1 homologs) and proteasome degradation (DOA4, UBP5, RPT3, UBA1, UBP2, CDC48, UFD1, DOA1 and SHP1 homologs) were also significantly induced by DTT within $1 \mathrm{~h}$ of treatment. Up-regulation of vacuolar protein sorting (Cluster 9 in Figure 4, Tables 2, 4 and Additional file 2) and vesicle trafficking was observed in the DTT-treated cells (Table 4 and Additional file 2). 
A

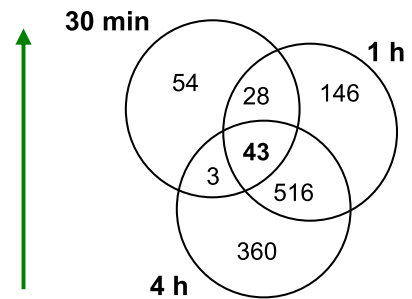

B

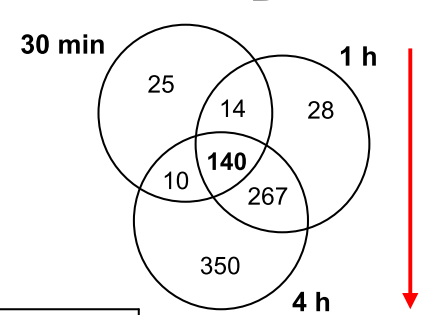

\begin{tabular}{|c|c|c|c|}
\cline { 2 - 4 } \multicolumn{1}{c|}{} & DTT 30 min & DTT 1 h & DTT 4 h \\
\hline$\uparrow$ & $128(2.7 \%)$ & $733(15.4 \%)$ & $922(19.4 \%)$ \\
\hline$\downarrow$ & $189(4.0 \%)$ & $449(9.4 \%)$ & $767(16.1 \%)$ \\
\hline$=$ & $4,442(93.3 \%)$ & $3,577(75.2 \%)$ & $3,070(64.5 \%)$ \\
\hline
\end{tabular}

D

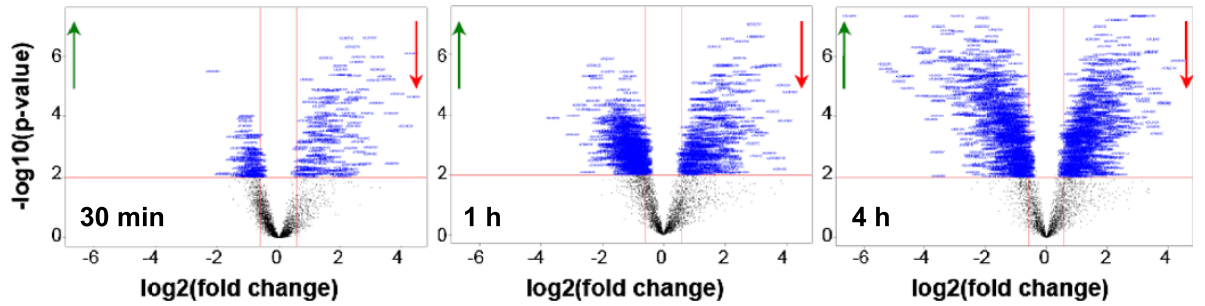

Figure 3 Overall variations in the $\boldsymbol{A}$. gossypii transcriptome after addition of DTT. The data refers to the outcome of the LIMMA analysis for differentially expressed genes within $30 \mathrm{~min}, 1 \mathrm{~h}$ and $4 \mathrm{~h}$ of exposure to DTT, when compared to the time immediately before DTT addition (fold change $>1.5$ and p-value $<0.01)$. The Venn diagrams indicate the number of genes that had increased $(\mathbf{A})$ or reduced $(\mathbf{B})$ expression after $30 \mathrm{~min}, 1 \mathrm{~h}$ and $4 \mathrm{~h}$ of exposure to DTT. In table $(\mathbf{C})$ the absolute number and relative percentage (between brackets) of genes transcriptionally up-regulated $(\uparrow)$, down-regluated $(\downarrow)$ and unchanged $(=)$ by DTT after different exposure times are indicated. The Volcano plots $(\mathbf{D})$ obtained from the LIMMA analysis show the overall significant fold changes in the A. gossypii gene expression profiles after $30 \mathrm{~min}, 1 \mathrm{~h}$ and $4 \mathrm{~h}$ of DTT addition. Negative fold changes represent genes with increased $(\uparrow)$ expression and positive fold changes genes with reduced $(\downarrow)$ expression after exposure to DTT.

As mentioned above, DTT strongly and rapidly repressed the protein glycosylation pathway in A. gossypii (Table 3 and Additional file 2). The A. gossypii YOS9 and HTM1/MNL1 homologs, which in S. cerevisiae encode two proteins that are required for the ERAD of misfolded glycoproteins [41], were also repressed by DTT. Several genes involved in the COPI retrograde transport of proteins from the Golgi back to the ER were induced by DTT within $1 \mathrm{~h}$ of exposure (Additional file 2), which might have favoured the recycling of proteins. Some genes involved in the ER to Golgi protein trafficking were also induced by DTT, but COPII vesicle-mediated transport was strongly repressed by DTT (Additional file 2).

Genes involved in translation were down-regulated by DTT, but only after 4 h of treatment (Cluster 1 in Figure 4, Tables 2 and 3). DTT also repressed the transcription of the A. gossypii SSH1 homolog, which in S. cerevisiae is involved in the co-translational translocation of proteins into the ER [42]. On the other hand, genes involved in mRNA degradation, such as DOM34, KEM1, SKI2, SKI3, SKI7, LSM2 and NMD2 homologs, were up-regulated by DTT within $1 \mathrm{~h}$ of treatment.
Thirty percent of the genes whose transcription was significantly decreased $30 \mathrm{~min}$ after DTT addition (p-value $<0.01$ for a fold-change $>1.5$ ) were predicted to encode secretory proteins (Additional file 1: Table A1.3). This decreased to $15 \%$ after $1 \mathrm{~h}$ and to $10 \%$ after $4 \mathrm{~h}$ of treatment. Less than $5 \%$ of the significantly up-regulated genes were predicted to encode secretory proteins.

\section{Discussion}

The secretion of proteins by filamentous fungi is important for hyphal extension, degradation of substrates in natural ecosystems and pathogenicity $[13,43]$. Thus, many filamentous fungi have evolved to secrete high amounts of proteins. Previous observations have suggested that the secretion abilities of $A$. gossypii were more similar to those of closely related yeast species than to those of other filamentous fungi [2]. Here, we observed that the total protein concentration in the supernatants of $A$. gossypii submerged cultures with sucrose as primary carbon source was indeed relatively low ( $\leq 218 \mathrm{mg} / \mathrm{l}$ ). In silico analysis of the A. gossypii secretome predicted that it should represent around 1\% of the total proteome, a percentage closer to that predicted for yeast 
Table 2 Biological processes enriched $(p<0.01)$ in the co-expression clusters whose expression profiles varied differently in the DTT-treated vs. non-treated recombinant cells

\begin{tabular}{ll}
\hline Cluster $\mathbf{1}$ & Cluster $\mathbf{6}$ \\
\hline lon transport & Reproduction \\
Ribosomal large subunit biogenesis & Response to pheromone \\
Glycosylation & Ascospore wall assembly \\
Glycoprotein metabolic process & mRNA splicing, via splice \\
Macromolecule modification & Conjugation \\
Cellular iron ion homeostasis & M phase \\
Attachment of GPI anchor to protein & Peptide transport \\
Lipoprotein metabolic process & DNA recombination \\
Translational elongation & External encapsulating struc \\
Sulfur amino acid transport & Regulation of microtubu \\
Peptidyl-diphthamide biosynthetic process from peptidyl-histidine & depolymerization \\
&
\end{tabular}

\section{Cluster 2}

Reproduction

Organelle organization

Response to pheromone

Growth

Multi-organism process

Biological regulation

Transcription elongation from RNA polymerase II promoter

Conjugation

Gene expression

Regulation of transcription during mitosis

Mitotic cell cycle

Actin filament-based process

Isoleucyl-tRNA aminoacylation

Regulation of protein catabolic process

Protein localization to organelle

Chromosome segregation

Small GTPase mediated signal transduction

Cellular localization

Regulation of localization

Cell cycle

DNA-dependent transcription elongation

Proteolysis

Transcription from RNA polymerase II promoter

Macromolecule localization

Cellular macromolecule biosynthetic process

Regulation of biological process

\section{Cluster 7}

Endocytosis

Response to biotic stimulus

Positive regulation of homeostatic process

Proteasome assembly

Purine ribonucleoside catabolic process

Cell division

NAD biosynthesis via nicotinamide riboside salvage pathway

Amide biosynthetic process

Response to singlet oxygen

Membrane invagination

Response to osmotic stress

Response to abiotic stimulus

\section{Cluster 9}

Developmental process involved in reproduction

Vacuolar transport

Negative regulation of biological process

Response to stimulus

Autophagy

DNA-dependent transcription initiation

Cellular membrane fusion

Vacuolar protein processing

Post-translational protein modification

Cellular response to stress

Transcription initiation from RNA polymerase III promoter 
Table 2 Biological processes enriched $(p<0.01)$ in the co-expression clusters whose expression profiles varied differently in the DTT-treated vs. non-treated recombinant cells (Continued)

\begin{tabular}{ll}
\hline Nucleus organization & Macromolecule localization \\
Regulation of cell size & Cytokinesis \\
Transmembrane transport & DNA metabolic process \\
mRNA-binding (hnrnp) protein import into nucleus & Vesicle-mediated transport \\
Nuclear pore organization & Negative regulation of metabolic process \\
Nucleosome disassembly & Vacuole organization \\
& Cell communication \\
& Meiotic mismatch repair \\
\end{tabular}

Clusters 1 and 6 were down-regulated by DTT, whereas clusters 2, 7 and 9 were up-regulated by DTT (Figure 4).

secretomes (2-4\%) [13,44-47] than to that predicted for the secretomes of filamentous fungi $(5-8 \%)[13,48,49]$. However, in 2-D electrophoresis gel maps, $157-182$ protein spots (corresponding to approximately $3-4 \%$ of the A. gossypii total proteome) could be detected in the supernatants of $A$. gossypii cultures, indicating that, although in low amount, this fungus secreted a variety of proteins through the plasma membrane, possibly more than computationally predicted.

The existence of different isoforms of the same proteins (e.g. different glycoforms) may have contributed to the higher number of protein spots observed in 2-D gels (up to 182) than that computationally predicted (54). Moreover, not all proteins require secretion signals to get out of a cell. Several fungal species have been reported to secrete large amounts of proteins that lack the typical secretion signals of conventionally secreted proteins, via alternative vesicular pathways (reviewed in [50]). Thus, some protein spots may correspond to proteins secreted via an alternative secretory pathway, which would fail to be predicted as secreted by the computational tools used. The possible contribution of intracellular proteins for some of the weakest spots detected can also not be ruled out. Nevertheless, the results from both experimental and computational analyses indicated that $1-4 \%$ of $A$. gossypii proteins are secreted.

Of the 54 proteins that were predicted to comprise the A. gossypii secretome, less than 33\% were putative enzymes with hydrolytic activity. This is in line with the limited range of carbon sources which $A$. gossypii utilises $[51,52]$. Extracellular lipase [53], amylase [54] and $\beta$-glucosidase [54] activities have previously been found in $A$. gossypii culture supernatants. In agreement with these observations, one putative lipase (AER454C) and two putative $\beta$-glucosidases (AGL354C and AGL343C) were predicted to be secreted by $A$. gossypii. However, neither of the putative $A$. gossypii amylases (AEL044W and AEL276C) were predicted to contain a N-terminal signal peptide and, thus, would not be expected to be secreted via the general secretory pathway.
Although extracellular protease activity in A. gossypii supernatants has been reported as negligible [2], nine putative proteases (Additional file 1: Table A1.2) were predicted to be secreted, the majority of which would probably be most active at acidic $\mathrm{pH}$ [55]. Given that the optimum $\mathrm{pH}$ range for $A$. gossypii is 6-7 [52] and that only low concentrations of proteins are secreted by this fungus, extracellular protease activity would indeed be expected to be low or undetectable. An invertase (AFR529W) was also predicted to be secreted by this fungus and subsequent experimental characterization of this protein confirmed its function and secretion into the culture supernatant [56]. Additionally, there was a putative acid phosphatase, a putative ureohydrolase and two putative FMN-binding proteins with probable oxidoreductase activity among the predicted secretome proteins, with no homologs in S. cerevisiae, but having homologs in Kluyveromyces lactis. Well-known extracellular proteins like $\alpha$-factor mating pheromones (AAR163C and AFL062W) were also predicted to be secreted.

The fact that $A$. gossypii secretes a rather small number of proteins, together with the low concentration in which they are produced and the negligible extracellular protease activity could be advantageous in heterologous protein production if high secretion levels of recombinant proteins are achieved, since secreted products would be unlikely to be contaminated or degraded by the native proteins ( $c f$. Pichia pastoris [47]). Moreover, a comprehensive analysis of the A. gossypii native secreted proteins could be used to facilitate product purification and quality control.

Despite these advantages, a major drawback of using A. gossypii for heterologous protein production is its low productivity [2]. Since eglI expression levels were much lower than those of the highly expressed TEF gene [57], we conclude that eglI was not highly overexpressed in the EGI producing cells and that a stronger promoter and/or better expression strategies would contribute to improving production and secretion of recombinant proteins by $A$. gossypii. Indeed, modifying the expression 
Table 3 Biological processes enriched $(p<0.001)$ in the gene clusters significantly down-regulated (fold change $>1.5$ and p-value $<0.01$ ) after $30 \mathrm{~min}, 1 \mathrm{~h}$ and $4 \mathrm{~h}$ of DTT treatment, in comparison with the time immediately before addition of DTT

30 min

Filamentous growth

\section{Response to copper ion}

Phytochelatin biosynthetic process

Lipid metabolic process

Barrier septum assembly

Positive regulation of catabolic process

\section{Carbohydrate metabolic process}

Hydrogen peroxide metabolic process

Glycoprotein metabolic process

Alditol biosynthetic process

Purine ribonucleoside monophosphate metabolic process

Acylglycerol biosynthetic process

Organic alcohol transport

Nucleoside transport

Lipid storage

Cadmium ion transport

Alcohol metabolic process

\section{Vitamin transport}

Nucleoside monophosphate metabolic process

\section{Glycosylation}

Organic ether metabolic process

Lipoprotein biosynthetic process

Purine base biosynthetic process

Lipoprotein metabolic process

Deadenylation-dependent decapping of nuclear-transcribed mRNA

Nucleobase metabolic process

Glycerol ether metabolic process

Cellular carbohydrate metabolic process

\section{$\mathrm{N}$-glycan processing}

Coenzyme a biosynthetic process

$\mathbf{1} \mathbf{h}$
'De novo' IMP biosynthetic process
Cadmium ion transport

Cadmium ion transport

Response to copper ion

Cell-cell adhesion

Iron assimilation

Polyphosphate metabolic process

\section{$\mathrm{N}$-glycan processing}

Peptide biosynthetic process

Glutamine metabolic process

Acylglycerol biosynthetic process

Organic alcohol transport

Thiamine transport

Endonucleolytic cleavage to

generate mature $3^{\prime}$-end of ssu-rRNA from (ssu-rRNA, 5.8 s rRNA, Isu-rRNA)

\section{Lipid storage}

Organic ether metabolic process Vitamin transport

Nucleoside monophosphate metabolic process

Ctp metabolic process

Nucleobase-containing compound biosynthetic process

Glycerol ether metabolic process

\section{$4 \mathrm{~h}$}

Adenine salvage

Cadmium ion transport

Response to copper ion

Organophosphate metabolic process

Polyphosphate metabolic process

Cellular oligosaccharide metabolic process

Group II intron splicing

Triglyceride biosynthetic process

Mannoprotein biosynthetic process

Thiamine transport

Cellular biosynthetic process

Regulation of translational fidelity

\section{Vitamin transport}

Glycoprotein metabolic process

\section{Lipid storage}

Septin checkpoint

Protein metabolic process

Box c/d snoRNA metabolic process

Nucleoside metabolic process

Nucleoside monophosphate metabolic process

\section{Glycosylation}

Regulation of mating-type specific transcription, DNA-dependent

Cell wall glycoprotein biosynthetic process

Purine nucleoside metabolic process

Nucleobase-containing compound biosynthetic process

GO terms highlighted in bold were overrepresented at two or all (bold italic) DTT exposure times. 
Table 4 Biological processes enriched $(p<0.001)$ in the gene clusters significantly up-regulated (fold change $>1.5$ and p-value $<0.01$ ) after $30 \mathrm{~min}, 1 \mathrm{~h}$ and $4 \mathrm{~h}$ of DTT treatment, in comparison with the time immediately before addition of DTT

\begin{tabular}{|c|c|c|}
\hline $30 \mathrm{~min}$ & $1 \mathrm{~h}$ & $4 \mathrm{~h}$ \\
\hline Spermine biosynthetic process & Protein unfolding & DNA dealkylation involved in DNA repair \\
\hline \multirow[t]{2}{*}{ Interspecies interaction between organisms } & Bipolar cellular bud site selection & \\
\hline & Early endosome to golgi transport & Carbon utilization \\
\hline S-adenosylmethionine transport & Membrane docking & Asexual reproduction \\
\hline \multirow[t]{2}{*}{ Traversing start control point of mitotic cell cycle } & Trehalose biosynthetic process & Response to stimulus \\
\hline & Phosphorus metabolic process & $\begin{array}{l}\text { Negative regulation of transferase } \\
\text { activity }\end{array}$ \\
\hline Macromolecule metabolic process & Regulation of DNA repair & \\
\hline \multirow[t]{2}{*}{ Glucose 1-phosphate metabolic process } & Fructose transport & Early endosome to golgi transport \\
\hline & Asymmetric protein localization & Cellular aldehyde metabolic process \\
\hline \multirow[t]{2}{*}{ Cis assembly of pre-catalytic spliceosome } & Vesicle-mediated transport & $\begin{array}{l}\text { NAD biosynthesis via nicotinamide } \\
\text { riboside salvage pathway }\end{array}$ \\
\hline & mRNA polyadenylation & \\
\hline Macromolecule catabolic process & Cellular localization & Trehalose biosynthetic process \\
\hline Protein unfolding & Cell wall macromolecule catabolic process & Protein unfolding \\
\hline Golgi localization & & Nuclear mRNA 5'-splice site recognition \\
\hline Leading strand elongation & Secretion & \\
\hline \multirow[t]{2}{*}{ Cellular macromolecule metabolic process } & Macromolecule localization & Asymmetric protein localization \\
\hline & Cofactor transport & Secretion \\
\hline \multirow{3}{*}{$\begin{array}{l}\text { Negative regulation of transcription from } \\
\text { RNA polymerase II promoter during mitosis }\end{array}$} & Oligosaccharide metabolic process & Sodium ion transport \\
\hline & Macromolecule catabolic process & $\begin{array}{l}\text { Negative regulation of developmental } \\
\text { process }\end{array}$ \\
\hline & Positive regulation of lipid metabolic process & \\
\hline Proteolysis & & Oligosaccharide metabolic process \\
\hline \multirow[t]{2}{*}{ Transcription initiation, DNA-dependent } & Transcription from RNA polymerase II promoter & Tetrapyrrole catabolic process \\
\hline & & Intron homing \\
\hline Stress-activated protein kinase signaling cascade & Negative regulation of catalytic activity & $\begin{array}{l}\text { Negative regulation of catalytic } \\
\text { activity }\end{array}$ \\
\hline \multirow[t]{2}{*}{ Negative regulation of transferase activity } & Regulation of hydrolase activity & Regulation of hydrolase activity \\
\hline & Regulation of transferase activity & Regulation of transferase activity \\
\hline \multirow[t]{3}{*}{ Trehalose biosynthetic process } & Proteolysis & Glycerophospholipid catabolic process \\
\hline & Regulation of response to stimulus & \\
\hline & Negative regulation of developmental process & \\
\hline
\end{tabular}

GO terms highlighted in bold were overrepresented at two or all (bold italic) DTT exposure times.

vector resulted in a 2 fold increase in extracellular EGI activity [54], while use of the A. gossipii native TEF promoter substantially improved production of recombinant $\beta$-galactosidase from Aspergillus niger, leading to relatively high levels of secretion [58]. Enhancement of the protein translation efficiency could also increase the production of secreted proteins, as indicated by the down-regulation of some genes involved in regulation of protein translation during EGI secretion.
Previous studies have shown that secretion of recombinant proteins can lead to secretion stress and trigger the UPR, which modulates both general and proteinspecific transcriptional responses [6,14,36,59]. This did not occur in A. gossypii, probably because egl1 was not highly expressed and thus EGI production did not constitute a major burden to the cells. Carvalho et al. [60] recently shown that, in A. niger, the induction of the UPR pathway is dependent on the level of heterologous gene 


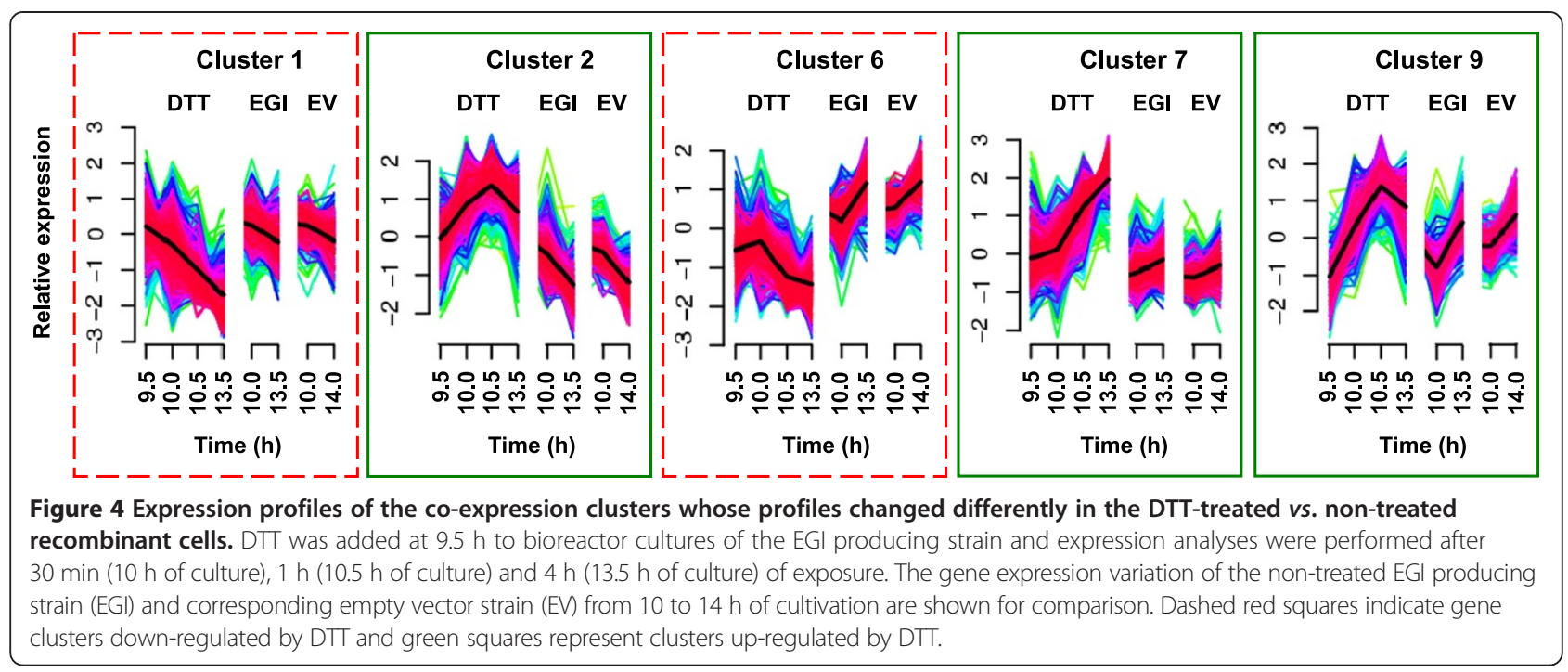

expression. Under relative low-expressing conditions, the basal protein folding and quality control machinery of the A. niger ER was adequate, but under high-expressing conditions ER stress was induced [60].

We induced secretion stress in A. gossypii cells with DTT, since it was not induced by EGI production. DTT has been widely used to induce secretion stress in investigations of the UPR $[6,30,36,59,61-63]$, even though it is not a specific secretion stress inducer, inducing other stresses, such as oxidative stress, as well. Transcription of genes that may not be closely related to the UPR is also affected, as observed in a transcriptomic comparison of Aspergillus nidulans cells stressed by DTT treatment or by recombinant chymosin secretion, which showed similar changes in the expression of some genes, but not others
[6]. However, DTT has consistently induced the UPR in various yeast and filamentous fungi $[6,30,36,59,61-63]$.

DTT did not trigger a conventional UPR in A. gossypii, as the expression levels of several well-known UPR target genes (such as IRE1, HAC1, KAR2, PDI1 and EUG1) remained unchanged and no UPRE-like motif was overrepresented in the gene clusters up-regulated by DTT. The amount of DTT used in this study $(10 \mathrm{mM}$ final concentration) was comparable to that used in several other studies with yeast and filamentous fungi (2-10 mM) [30,61-63]. To our knowledge, only in studies of $A$. nidulans and $A$. niger has DTT been added to the cultures at a higher concentration $(20 \mathrm{mM})[6,59]$.

Although a classical UPR was not induced, there was evidence of secretion stress induced by DTT in A. gossypii

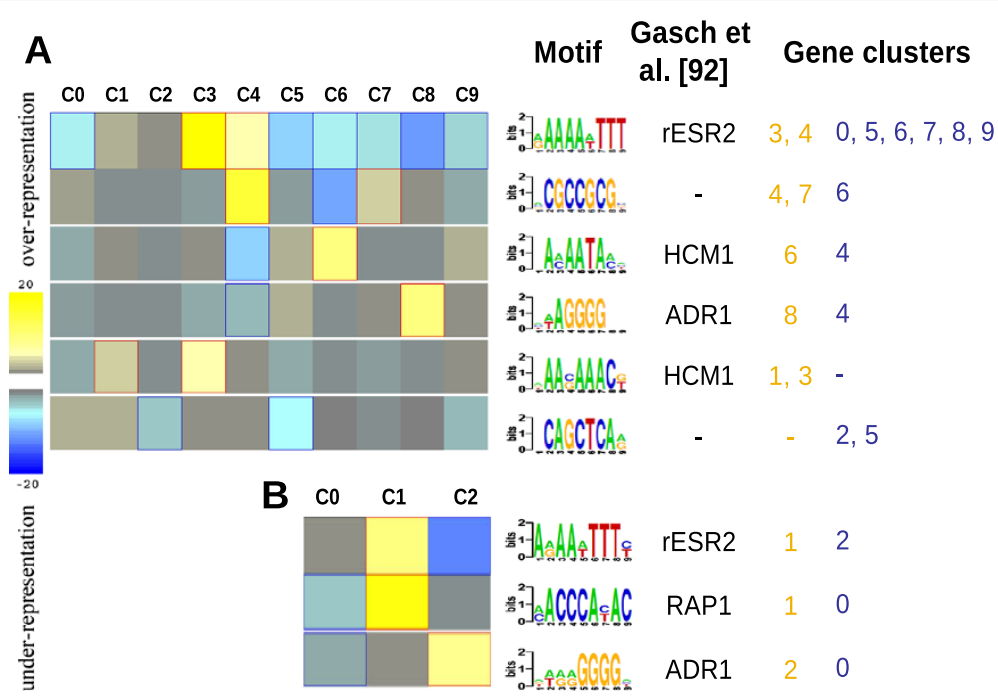

Figure 5 Regulatory DNA elements significantly over- (yellow) and under-represented (blue) $(p<0.05)$ in different gene clusters. In panel $\mathbf{A}$ are represented the co-expression clusters and in panel $\mathbf{B}$ the clusters of genes differentially up- (C1) and down-regulated (C2) by DTT. CO comprises the genes that were not included in any of the other clusters. 
cells (Figure 6). Expression of several genes involved in protein unfolding, ERAD, proteasome degradation, proteolysis, vesicle trafficking, vacuolar protein sorting and secretion significantly increased within $1 \mathrm{~h}$ of DTT treatment. In fungi, the UPR was thought to be exclusively dependent on Ire1p-mediated splicing of HAC1 mRNA. However, an IRE1-, HAC1- and UPRE-independent pathway for transcriptional activation upon ER stress exists in S. cerevisiae, which may activate a core promoter through stimulation of RNA polymerase II holoenzyme activity [64]. Miyazaki et al. [28] have also demonstrated that Candida glabrata has lost the classic Ire1p-Hac1p UPR, but instead possesses an alternative mechanism, RIDD. In $A$. gossypii, the expression of several genes involved in mRNA degradation was induced by DTT, which suggests that a RIDD-like mechanism may exist in A. gossypii to reduce the ER load when there is secretion stress. Another mechanism to alleviate the load of proteins in the ER in some fungi is the transcriptional down-regulation of genes encoding secreted proteins in response to secretion stress (RESS). This down-regulation mechanism has been described in T. reesei [65], A. niger [66] and S. cereviaise [67]. In A. gossypii, DTT also repressed the transcription of a large number of genes encoding putative secretory proteins.

Two of the genes, encoding a subunit of the translocon complex (Ssh1p) and a chaperone involved in the translocation of newly synthesised proteins into the ER (Lhs1p), which were repressed by DTT may have contributed to accumulation of unfolded proteins in the cytosol. Intriguingly, most of the genes involved in protein folding that were up-regulated by DTT encoded cytosolic chaperones, co-chaperones and nucleotide exchange factors (Additional file 2). A stress response induced by misfolded cytosolic proteins that do not enter the secretory pathway, called UPR-Cyto, has been preliminarily characterized in S. cerevisiae [68,69]. This cytosolic stress response induces the production of several cytosolic chaperones and co-chaperones. The UPR-Cyto response appears to be a specific HSF1-mediated module of the eukaryotic heat shock response $[68,69]$. The transcript level of the HSF1 homolog in DTT-stressed A. gossypii cells was only slightly increased. Moreover, no Hsf1p-like consensus binding sequence was overrepresented in the gene clusters analyzed. Thus, an UPR-Cyto may have been activated in A. gossypii in response to secretion stress induced by DTT, but probably not by Hsflp.

Another striking difference in the A. gossypii transcriptional responses to DTT-induced stress, compared to that of $S$. cerevisiae, A. niger or $T$. reesei, was the rapid and severe down-regulation of the protein glycosylation pathway, an effect that at similar extent has only been described for treatments with tunicamycin. This could lead to an accumulation of improperly glycosylated proteins. In mammals, calnexin provides chaperone activity to retain incompletely glycosylated proteins in the ER, functioning as a component of the glycoprotein quality control system in the ER [70]. The S. cerevisiae homolog Cne1p also binds specifically to monoglucosylated oligosaccharides [71]. However, no homolog for the CNE1 was found in the A. gossypii genome. An alternative mechanism of quality control should, therefore, exist to balance this absence.

Like the ER, the Golgi complex may also be involved in conformation-based disposal of abnormal proteins targeted for degradation [72]. Here we show that several post-ER pathways for protein disposal were up-regulated upon DTT treatment in A. gossypii. These included both the retrograde transport of proteins back to the ER for ERAD (via COPI-vesicle mediated transport) and protein transport via the endosomal system for degradation. COPII-vesicle mediated export of proteins from the ER to the Golgi was, however, down-regulated by DTT.

\section{Conclusion}

Our results show that the lack of an active conventional UPR in $A$. gossypii may be compensated by alternative pathways, probably working simultaneously, to relieve the cells from secretion stress. The fact that A. gossypii

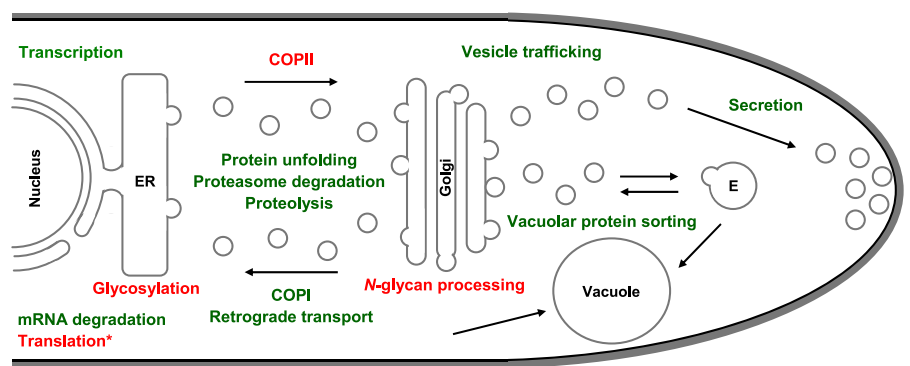

Figure 6 Schematic representation of the A. gossypii protein secretory pathway with indication of relevant functions significantly up- (green) or down-regulated (red) by DTT-induced stress. ${ }^{*}$ ) Biological function down-regulated under recombinant EGI secretion conditions as well, (E) Endosome. 
has one of the smallest eukaryotic genomes known and, consequently, reduced genetic machinery, may have contributed to the differences between its transcriptional responses to secretion stress and those reported for other fungal species. The absence of a calnexin homolog in A. gossypii indicates that it lacks some of the ER quality control mechanisms of other fungi.

Despite the high genetic similarity it shares with $S$. cerevisiae, the regulation of the protein secretory pathway of A. gossypii and S. cerevisiae differed considerably. It must not be forgotten that significant sequence similarity between $A$. gossypii and S. cerevisiae is restricted to coding regions [73] and that regulatory genes are reported to show a higher evolutionary rate than structural genes, resulting in homologous transcriptional factors playing different regulatory functions in different organisms $[74,75]$. Therefore, although earlier results have shown that the $A$. gossypii protein secretion potential is more similar to yeast than to other filamentous fungi, reflecting phylogentic relationships rather than morphology, the differences in regulation may suggest novel ways of improving protein secretion in A. gossypii.

\section{Methods}

\section{Strains and culture conditions}

A. gossypii ATCC 10895, kindly provided by Prof. P. Philippsen (Biozentrum, University of Basel, Switzerland) and here referred to as the parental strain, was used for proteomic analyses. A recombinant A. gossypii EGI producing strain (VTT D-101398) and its corresponding empty vector control strain described in Ribeiro et al. [2] were used for transcriptomic analyses. Stock cultures were maintained as spores suspended in $20 \%(\mathrm{v} / \mathrm{v})$ glycerol, $0.8 \%(\mathrm{w} / \mathrm{v}) \mathrm{NaCl}$ with $0.025 \%(\mathrm{v} / \mathrm{v})$ Tween 20 at $-80^{\circ} \mathrm{C}$.

Pre-cultures to inoculate bioreactors were grown in $250 \mathrm{ml}$ Erlenmeyer flasks containing $50 \mathrm{ml}$ of AFM (1\% $(\mathrm{w} / \mathrm{v})$ yeast extract, $1 \%(\mathrm{w} / \mathrm{v})$ tryptone, $2 \%(\mathrm{w} / \mathrm{v})$ glucose and $0.1 \%$ (w/v) myo-inositol), which was supplemented with $200 \mu \mathrm{g} / \mathrm{ml} \mathrm{G418} \mathrm{(Sigma)} \mathrm{for} \mathrm{maintenance} \mathrm{of} \mathrm{the} \mathrm{re-}$ combinant strains. A. gossyppii pre-cultures were inoculated with $10^{6}$ spores and grown for $14-17 \mathrm{~h}$ at $30^{\circ} \mathrm{C}$ and $200 \mathrm{rpm}$.

For cultivation of the recombinant strains, Biostat ${ }^{\oplus}$ CT bioreactors, maximum working volume of 2.51 (B. Braun Biotech International, Sartorius AG), containing 1.51 or 21 of AFM plus $200 \mu \mathrm{g} / \mathrm{ml}$ G418 were used. Biostat ${ }^{\circ}$ B-DCU bioreactors, maximum working volume of 21 (B. Braun Biotech International, Sartorius AG), were used for cultivation of the parental strain in $1 \mathrm{l}$ of either modified AFM or defined minimal medium [76], both containing $2 \%(\mathrm{w} / \mathrm{v})$ sucrose as carbon source instead of glucose. Bioreactors were inoculated to an initial biomass of $0.13 \pm 0.08 \mathrm{~g} / \mathrm{l}$, for recombinant strains, or $0.60 \pm 0.05 \mathrm{~g} / \mathrm{l}$, for the parental strain. Cultures were grown at $30^{\circ} \mathrm{C}$ and $500 \mathrm{rpm}$, with 1.0 volume of gas per volume of culture per minute (vvm) aeration. Culture $\mathrm{pH}$ was kept at $6.0 \pm 0.1$ by the addition of $1 \mathrm{M} \mathrm{KOH}$ or $1 \mathrm{M} \mathrm{H} \mathrm{H}_{3} \mathrm{PO}_{4}$. Polypropylene glycol (mixed molecular weights) [77] was added to prevent foaming. Gas concentration $\left(\mathrm{CO}_{2}, \mathrm{O}_{2}, \mathrm{~N}_{2}\right.$ and Ar) was analyzed continuously in an Omnistar quadrupole mass spectrometer (Balzers AG), calibrated with $3 \% \mathrm{CO}_{2}$ in Ar.

For dry weight determination, culture samples were filtered through pre-dried and pre-weighed Whatman GF/B glass fibre filters, washed with at least two sample volumes of double-distilled water and dried to a constant weight at $105^{\circ} \mathrm{C}$. Aliquots of the culture filtrates were stored at $-20^{\circ} \mathrm{C}$.

Residual sugars and produced metabolites in the culture filtrates were quantified by high performance liquid chromatography (HPLC) as previously described [78]. Total protein concentration in the cell-free broth was measured using the Thermo Scientific Pierce Coomassie (Bradford) Protein Assay kit, with bovine serum albumin (BSA) as standard. The activity of secreted EGI in the culture filtrates was determined as described in Ribeiro et al. [2], using 4-methylumbelliferyl- $\beta$-D-lactoside (MULac) (Sigma) as substrate. Volumetric EGI enzyme activity was defined as micromoles of 4-methylumbelliferone (MU) (Sigma) formed per minute and per litre of culture $\left(\mu \mathrm{mol} \mathrm{min}^{-1} \mathrm{l}^{-1}\right.$ ) under the assay conditions.

For gene expression analysis, mycelial samples from the recombinant strains were collected from duplicate bioreactor cultivations $4 \mathrm{~h}, 7 \mathrm{~h}, 10 \mathrm{~h}$ and $13.5 \mathrm{~h}$ after inoculation. After $9.5 \mathrm{~h}$, DTT was added to two out of four A. gossypii VTT D-101398 cultures at a final concentration of $10 \mathrm{mM}$. Samples from DTT-treated cultures were collected $30 \mathrm{~min}, 1 \mathrm{~h}$ and $4 \mathrm{~h}$ after DTT addition. Mycelium was rapidly separated from the culture supernatant by filtration through Whatman GF/B glass fibre filters, washed with two sample volumes of $0.9 \%(\mathrm{w} / \mathrm{v}) \mathrm{NaCl}$, frozen immediately in liquid nitrogen and stored at $-80^{\circ} \mathrm{C}$.

\section{In silico secretome prediction}

A computational approach similar to those described to predict the secretomes of Candida albicans [44], K. lactis [45,46], P. pastoris [47] and Trichoderma species [49] was used to analyze the putative protein sequences of the 4,776 ORFs annotated in the A. gossypii genome (ftp://ftp. ncbi.nlm.nih.gov/genomes/Fungi/Eremothecium_gossy pii_uid10623/, accessed on December 2012). In this protocol, SignalP version 3 [79] was used to identify the presence of N-terminal signal peptides and TMHMM version 2 [80] was used to identify putative transmembrane regions in proteins with putative signal peptides. Only proteins with signal peptides predicted by the SignalP Neural Networks and Hidden Markov Models were included. Proteins with 1 predicted transmembrane spanning region 
were kept in the dataset if it was located in the $\mathrm{N}$-terminal region before the predicted signal peptide cleavage site. Sequences with more than 1 transmembrane spanning region were excluded. TargetP version 1.1 [10] and the fungal version of big-PI [81] were then used to eliminate proteins predicted to be targeted to the mitochondrion and/or to contain a GPI anchor. Finally, WoLF PSORT [11] was used for sub-cellular localization prediction. The default value for the total number or nearest neighbors $(k)$ was 27 and only proteins with a $k>13$ for extracellular location were included in the secretome. The NetNGlyc version 1.0 server [www.cbs.dtu.dk/services/NetNGlyc/] was used to predict $N$-glycosylation sites and the databases UniProt (www.uniprot.org) [82], CAZy (www.cazy.org) [83] and MEROPS (http://merops.sanger.ac.uk) [55] were used to retrieve predicted functions for $A$. gossypii putative proteins. The EMBOSS pepstats application (http://emboss. bioinformatics.nl/cgi-bin/emboss/pepstats) [84] was used to calculate the theoretical molecular weight and isoelectric point for each putative protein.

\section{Gel electrophoresis of secreted proteins}

The proteins present in $15 \mu \mathrm{l}$ of culture supernatant were analyzed by $12 \%(\mathrm{w} / \mathrm{v})$ SDS-PAGE followed by silver staining.

For 2-D gel electrophoresis, the total proteins in parental strain culture filtrates collected at the beginning of the stationary phase were precipitated overnight at $-20^{\circ} \mathrm{C}$ in $10 \%(\mathrm{w} / \mathrm{v})$ trichloroacetic acid and $66.6 \%(\mathrm{v} / \mathrm{v})$ acetone. The pellet was washed with ice-cold acetone, dried and resuspended (15 min at room temperature) in 2-D sample solution (8 M urea, $10 \mathrm{mM}$ DTT, 2\% (v/v) Pharmalyte 3-10 (GE Healthcare) and 2\% (v/v) Triton X-100). Insoluble material was removed by centrifugation and the protein concentration in the samples was determined using the 2-D Quant Kit (GE Healthcare). Each sample was independently prepared and used for duplicate 2-D electrophoresis analyses.

Equal amounts of total extracellular protein $(100 \mu \mathrm{g})$ were cup-loaded in Immobiline DryStrip gel strips pH 3-10, $18 \mathrm{~cm}$ (GE Healthcare) previously rehydrated and subjected to isoelectric focusing (IEF) using an Ettan IPGphor II (GE Healthcare) according to the instructions of the manufacturer. The first-dimension isoelectric focusing was followed by second-dimension $11 \%(\mathrm{w} / \mathrm{v})$ SDSPAGE using an Ettan DALT electrophoresis system (GE Healthcare). After electrophoresis, the gels were fixed for $30 \mathrm{~min}$ with $30 \%(\mathrm{v} / \mathrm{v})$ ethanol and $0.5 \%(\mathrm{v} / \mathrm{v})$ acetic acid in water and subsequently stained with SYPRO Ruby (Bio-Rad) according to the instructions of the manufacturer. The 2-D gels were scanned in a Typhoon 8610 variable mode imager (GE Healthcare) at 300 dpi resolution and gel images analysed with Melanie software version 7.0 (Geneva Bioinformatics (GeneBio) SA). After automatic spot detection, artefacts were manually removed and the weaker spots $(<0.1 \%$ of the whole gel volume) were eliminated. The remaining spots were then linked to allow comparison between samples.

\section{RNA extraction and gene expression analysis}

Total RNA extraction from frozen mycelium was carried out using the RNeasy Plant Mini kit (QIAGEN) according to the manufacturer's instructions for isolation of total RNA from filamentous fungi. RNA concentration and purity were determined using a NanoDrop ND-1000 (NanoDrop Technologies) and integrity of RNA was analyzed using an Agilent 2100 Bioanalyzer (Agilent Technologies).

For microarray analysis, custom-made A. gossypii gene expression $12 \times 135 \mathrm{~K}$ arrays were designed and manufactured by Roche NimbleGen. Each slide contained 12 independent arrays, each comprising four replicates of 33,364 probes covering 4,758 ORFs of $A$. gossypii and the T. reese $i$ egl1 gene (7 probes/target ORF). $10 \mu \mathrm{g}$ of total RNA were used for reverse transcription and synthesis of cDNA using the SuperScript II Double-Stranded cDNA Synthesis Kit (Invitrogen) according to the Roche NimbleGen Arrays User's Guide: Gene Expression Arrays v5.0, available from the NimbleGen website [www.nimblegen.com]. The cDNA was quantified in a NanoDrop ND-1000 (NanoDrop Technologies) and its integrity analyzed using an Agilent 2100 Bioanalyzer (Agilent Technologies). The double-stranded cDNA was labelled with Cy3 fluorescent dye, hybridized to the custom-made microarray slides (Roche NimbleGen) and scanned using a NimbleGen MS 200 Microarray Scanner (Roche NimbleGen) according to the instructions of the manufacturer.

For qPCR, $1 \mu \mathrm{g}$ of total RNA was reverse transcribed using the NZY First-Strand cDNA Synthesis Kit (NZYTech) and qPCR analyses were performed as previously described $[56,85]$, with the primer pairs shown in Additional file 3: Table A3.1.

\section{Microarray data analysis}

The raw array data obtained from NimbleScan software version 2.5.26 (Roche NimbleGen) was preprocessed with the Robust Multichip Average (RMA) method [86]. Array data quality was controlled with arrayQualityMetrics [87] and sample wise Principal Component Analysis (PCA) of raw, RMA preprocessed and repeat averaged data. Linear Models for Microarrays (LIMMA) [88] was subsequently used to select significantly changing genes with a cut-off of $\mathrm{p}$-value $<0.01$ (which corresponds to a false discovery rate (FDR) of $1 \%$ in this analysis) and fold-change $>1.5$. For each gene its Pearson correlation with EGI activity ( $\mu \mathrm{mol} \mathrm{min}^{-1} \mathrm{l}^{-1}$ ) was calculated. The FDR of these correlations $(4.4 \%$ for absolute correlation >0.7) was estimated from the Q-value [89] using the $\mathrm{R}$ package 'qvalue'. 
Each gene's repeat averaged expression values over all the samples i.e. expression profiles were clustered with R-package 'Mfuzz' [90] with parameter $m$ set to 1.35 and number of clusters to 9. Parameters were selected based on visual evaluation of cluster profiles. Genes with cluster membership $>0.7$ were assigned to a co-expression cluster for further analysis.

A. gossypii gene mappings to S. cerevisiae genes from the Ashbya Genome Database (http://agd.vital-it.ch) [91] were used to map the array results of differential gene expression, gene expression correlation with EGI activity $\left(\mu \mathrm{mol} \mathrm{min}{ }^{-1} \mathrm{l}^{-1}\right.$ ) and co-expression clusters to S. cerevisiae. GO class analyses used $S$. cerevisiae GO annotations. The R-package 'GSA' [92] was used for the GO analysis of differential expression of genes, the R-package 'GOstats' [93] was used to analyse gene expression correlation and co-expression clusters and REVIGO [94] was used to summarize the GO term lists.

Promoter sequences were analysed with the tool Finding Informative Regulatory Elements (FIRE) [95], with default settings using the $A$. gossypii genome. Co-expression clusters and clusters of differentially expressed genes were used as groups of genes from which to find common promoter elements. Genes which were not assigned to any cluster were assigned to group number 0 for this analysis. As promoter we used 1500 bases upstream from the putative ORF of each gene. The identified promoter elements were mapped with FIRE to the known promoter elements described in Gasch et al. [96] in order to annotate them.

\section{Availability of supporting data}

The data sets supporting the results of this article are included within the article (and its additional files). The raw microarray data was deposited in GEO with accession number GSE62366.

\section{Additional files}

\section{Additional file 1: A. gossypii secretome and microarray gene}

expression analysis data. Table A1.1. Secretome analysis data. According to our protocol proteins were predicted to be secreted if: (a) contained a signal peptide predicted by both SignalP methods (NN D-score SP=" $Y^{\prime \prime}$ and HMM Pred="S"); (b) did not contain predicted transmembrane spanning regions (PredHel $="{ }^{\prime \prime}$ ) or this was located in the N-terminal region before the predicted signal peptide cleavage site (PredHel=" $1{ }^{* \prime \prime}$; (c) were predicted not to be targeted to the mitochondrion (loc $\neq$ " $\mathrm{M}^{\prime \prime}$ ): (d) did not contain predicated GPI anchors (big-PI Quality="P" or "P or S"); and (e) presented a k>13 for extracellular location predicted by WoLF PSORT. Table A1.2. A. gossypii predicted secretome. A. gossypii ORFs encoding the putative proteins predicted to be secreted to the extracellular space and corresponding S. cerevisiae homologs. Predicted functions, number of $\mathrm{N}$-glycosylation sites, theoretical molecular weights (MW) and isoelectric points (pl) are also indicated. Table A1.3. Microarray gene expression analysis data. "Best Cluster" show the co-expression cluster to which genes were assigned (cluster membership $>7$ ) after clustering their expression profiles with the R-package 'Mfuzz' ( $m=1.35,9$ clusters). "log2(fold change)" show the fold change of the averaged RMA preprocessed signal of each gene's repeat upon DTT treatment or in EGl producing vs. non-EGl producing cultures at the indicated times. "Significance" show the results of a significance test ( $R$ package LIMMA, p-value<0.01, log 2 fold change $>0.58), 1$ indicates up-regulation and -1 down-regulation. "q-value", "p-value" and "Absolute correlation $>0.7$ " show the results from the Pearson correlation of each gene's expression to $\mathrm{EGl}$ activity ( $\mu \mathrm{mol} \mathrm{min}^{-1} \mathrm{I}^{-1}$ ) in $\mathrm{EGl}$ producing conditions, 1 indicates up-regulation and -1 down-regulation during EGl production (FDR of $4.4 \%$ for absolute correlation $>0.7$ ). "NN D-score SP" and "HMM Pred" indicate putatively encoded secretory proteins as predicted by both SignalP methods (NN D-score $\mathrm{SP}=" \mathrm{Y}$ " and HMM Pred="S/A").

Additional file 2: Secretion-related $A$. gossypii genes with significant fold changes ( ${ }^{a} \mathrm{p}$-value $<0.01$ ) in their transcript levels after treatment with DTT for $30 \mathrm{~min}, \mathbf{1} \mathrm{h}$ and $\mathbf{4} \mathrm{h}$. The corresponding S. cerevisiae homologs are indicated, as well as predicted functions. Green indicates up-regulation and red down-regulation by DTT.

Additional file 3: qPCR results of selected genes and primer sequences used. Figure A3.1. Expression analysis of selected genes by QPCR in the EGl expressing strain immediately before (DTT $0 \mathrm{~h}$ ) and $1 \mathrm{~h}$ after addition of DTT (DTT 1 h). No significant changes $(p>0.2)$ were observed in the expression of the selected genes $1 \mathrm{~h}$ after addition of DTT. The gene expression levels were normalized to the expression level of AgACT1. Data represents the mean \pm standard deviation of two independent bioreactor cultures. Each cDNA sample was analyzed in triplicate and the coefficient of variation between the results for these technical replicas was $<30 \%$. Table A3.1. Primers used in the qPCR analysis.

\section{Abbreviations}

2-D: Two-dimensional; AFM: Ashbya full medium; bZIP: Basic-leucine zipper; DMM: Defined minimal medium; DTT: Dithiothreitol; ER: Endoplasmatic reticulum; EGI: Endoglucanase I; ERAD: ER-associated degradation; FDR: False discovery rate; FIRE: Finding informative regulatory elements; GO: Gene ontology; LIMMA: Linear models for microarrays; qPCR: Quantitative PCR; RMA: Robust multi-array average; RIDD: Regulated IRE1-dependent decay; SDS-PAGE: Sodium dodecyl sulfate polyacrylamide gel electrophoresis; UPR: Unfolded protein response; UPRE: UPR elements; Vvm: Volume of gas per volume of culture per minute.

\section{Competing interests}

The authors declare that they have no competing interests.

\section{Authors' contributions}

Conceived and designed the experiments: TQA, OR, MGW, MP and LD. Performed the experiments: TQA, OR and MGW. Analyzed the data: TQA, OR and MA. Wrote the manuscript: TQA, OR and MA. All authors read and approved the final manuscript.

\section{Acknowledgments}

This work was financially supported by Fundação para a Ciência e a Tecnologia, Portugal, through: PhD grant SFRH/BD/30229/2006 to OR, MIT-Portugal Program PhD grant SFRH/BD/39112/2007 to TQA, Project AshByofactory (PTDC/EBB-EBI/101985/2008 - FCOMP-01-0124-FEDER-009701), Project RECI/BBB-EBI/0179/2012 - FCOMP-01-0124-FEDER-027462, Strategic Project PEst-OE/EQB/LA0023/2013 and Project Biolnd (NORTE-07-0124-FEDER000028) co-funded by the Programa Operacional Regional do Norte (ON.2 - O Novo Norte), QREN, FEDER. We thank Dominik Mojzita and Mari Häkkinen from VIT Finland for their assistance with the microarray sample preparation, hybridization and data acquisition.

\section{Author details}

${ }^{1}$ CEB - Centre of Biological Engineering, University of Minho, 4710-057 Braga, Portugal. ${ }^{2}$ Department of Life Sciences, Imperial College London, Exhibition Road, London SW7 2AZ, UK. ${ }^{3} \mathrm{VTT}$ Technical Research Centre of Finland, Espoo, P.O. Box 1000, FIN-02044 VIT, Finland.

Received: 13 August 2014 Accepted: 20 November 2014 Published: 18 December 2014

\section{References}

1. Stahmann KP, Revuelta JL, Seulberger H: Three biotechnical processes using Ashbya gossypii, Candida famata, or Bacillus subtilis compete with chemical riboflavin production. Appl Microbiol Biotechnol 2000, 53:509-516. 
2. Ribeiro $\mathrm{O}$, Wiebe $M$, Ilmén $M$, Domingues $L$, Penttilä M: Expression of Trichoderma reesei cellulases CBHI and EGI in Ashbya gossypii. Appl Microbiol Biotechnol 2010, 87:1437-1446.

3. Dietrich FS, Voegeli S, Brachat S, Lerch A, Gates K, Steiner S, Mohr C, Pöhlmann R, Luedi P, Choi S, Wing RA, Flavier A, Gaffney TD, Philippsen P: The Ashbya gossypii genome as a tool for mapping the ancient Saccharomyces cerevisiae genome. Science 2004, 304:304-307.

4. Prillinger $\mathrm{H}$, Schweigkofler W, Breitenbach M, Briza P, Staudacher E, Lopandic K, Molnár O, Weigang F, Ibl M, Ellinger A: Phytopathogenic filamentous (Ashbya, Eremothecium) and dimorphic fungi (Holleya, Nematospora) with needle-shaped ascospores as new members within the Saccharomycetaceae. Yeast 1997, 13:945-960.

5. Gouka RJ, Punt PJ, van den Hondel CA: Efficient production of secreted proteins by Aspergillus: progress, limitations and prospects. Appl Microbiol Biotechnol 1997, 47:1-11.

6. Sims AH, Gent ME, Lanthaler K, Dunn-Coleman NS, Oliver SG, Robson GD: Transcriptome analysis of recombinant protein secretion by Aspergillus nidulans and the unfolded-protein response in vivo. Appl Environ Microbiol 2005, 71:2737-2747.

7. Resina D, Maurer M, Cos O, Arnau C, Carnicer M, Marx H, Gasser B, Valero F Mattanovich D, Ferrer P: Engineering of bottlenecks in Rhizopus oryzae lipase production in Pichia pastoris using the nitrogen source-regulated FLD1 promoter. Nat Biotechnol 2009, 25:396-403.

8. Yoon J, Aishan T, Maruyama J, Kitamotov K: Enhanced production and secretion of heterologous proteins by the filamentous fungus Aspergillus oryzae via disruption of vacuolar protein sorting receptor gene Aovps10. Appl Environ Microbiol 2010, 76:5718-5727.

9. Martoglio B, Dobberstein B: Signal sequences: more than just greasy peptides. Trends Cell Biol 1998, 8:410-415.

10. Emanuelsson O, Brunak S, von Heijne G, Nielsen H: Locating proteins in the cell using TargetP, SignalP and related tools. Nat Protoc 2007, 2:953-971.

11. Horton P, Park K, Obayashi T, Fujita N, Harada H, Adams-Collier C, Nakai K: WoLF PSORT: protein localization predictor. Nucleic Acids Res 2007 35:W585-W587.

12. Käll $L$, Krogh A, Sonnhammer EL: Advantages of combined transmembrane topology and signal peptide prediction - the Phobius web server. Nucleic Acids Res 2007, 35:W429-W432.

13. Lum G, Min XJ: FunSecKB: the Fungal Secretome KnowledgeBase. Database (Oxford) 2011, 2011:bar001.

14. Gasser B, Saloheimo M, Rinas U, Dragosits M, Rodríguez-Carmona E, Baumann K, Giuliani M, Parrilli E, Branduardi P, Lang C, Porro D, Ferrer P, Tutino ML, Mattanovich D, Villaverde A: Protein folding and conformational stress in microbial cells producing recombinant proteins: a host comparative overview. Microb Cell Fact 2008, 7:11.

15. Damasceno LM, Huang CJ, Batt CA: Protein secretion in Pichia pastoris and advances in protein production. Appl Microbiol Biotechnol 2012 93:31-39.

16. Stolz A, Wolf DH: Endoplasmic reticulum associated protein degradation: a chaperone assisted journey to hell. Biochim Biophys Acta 1803, 2010:694-705.

17. Kauffman KJ, Pridgen EM, Doyle FJ 3rd, Dhurjati PS, Robinson AS: Decreased protein expression and intermittent recoveries in BiP levels result from cellular stress during heterologous protein expression in Saccharomyces cerevisiae. Biotechnol Prog 2002, 18:942-950.

18. Rutkowski DT, Kaufman RJ: A trip to the ER: coping with stress. Trends Cell Biol 2004, 14:20-28.

19. Matsumoto $\mathrm{R}$, Akama $\mathrm{K}$, Rakwal $\mathrm{R}$, Iwahashi $\mathrm{H}$ : The stress response against denatured proteins in the deletion of cytosolic chaperones SSA1/2 is different from heat-shock response in Saccharomyces cerevisiae. BMC Genomics 2005, 6:141.

20. Mori K: Tripartite management of unfolded proteins in the endoplasmatic reticulum. Cell 2000, 101:451-454.

21. Walter $P$, Ron $D$ : The unfolded protein response: from stress pathway to homeostatic regulation. Science 2011, 334:1081-1086.

22. Cudna RE, Dickson AJ: Endoplasmic reticulum signaling as a determinant of recombinant protein expression. Biotechnol Bioeng 2003, 81:56-65.

23. Mori K: Signalling pathways in the unfolded protein response: development from yeast to mammals. J Biochem 2009, 146:743-750.

24. Cox JS, Shamu CE, Walter P: Transcriptional induction of genes encoding endoplasmatic reticulum resident proteins requires a transmembrane protein kinase. Cell 1993, 73:1197-1206.
25. Cox JS, Walter P: A novel mechanism for regulating activity of a transcription factor that controls the unfolded protein response. Cell 1996, 87:391-404.

26. Mori K, Kawahara T, Yoshida H, Yanagi H, Yura T: Signalling from endoplasmatic reticulum to nucleous: transcription factor with a basic-leucine zipper motif is required for the unfolded protein-response pathway. Genes Cells 1996, 1:803-817.

27. Hollien J, Weissman JS: Decay of endoplasmic reticulum-localized mRNAs during the unfolded protein response. Science 2006, 313:104-107.

28. Miyazaki T, Nakayama H, Nagayoshi Y, Kakeya H, Kohno S: Dissection of Ire1 functions reveals stress response mechanisms uniquely evolved in Candida glabrata. PLoS Pathog 2013, 9:e1003160.

29. Kaufman RJ: Stress signaling from the lumen of the endoplasmic reticulum: coordination of gene transcriptional and translational controls. Genes Dev 1999, 13:1211-1233.

30. Travers KJ, Patil CK, Wodicka L, Lockhart DJ, Weissman JS, Walter P. Functional and genomic analyses reveal an essential coordination between the unfolded protein response and ER-associated degradation. Cell 2000, 101:249-258.

31. Yorimitsu T, Nair U, Yang Z, Klionsky DJ: Endoplasmic reticulum stress triggers autophagy. J Biol Chem 2006, 281:30299-30304.

32. Leber JH, Bernales S, Walter P: IRE1-independent gain control of the unfolded protein response. PLOS Biol 2004, 2:e235.

33. Patil CK, Li H, Walter P: Gcn4p and novel upstream activating sequences regulate targets of the unfolded protein response. PLOS Biol 2004, 2:e246.

34. Hayes A, Zhang N, Wu J, Butler PR, Hauser NC, Hoheisel JD, Lim FL, Sharrocks AD, Oliver SG: Hybridization array technology coupled with chemostat culture: Tools to interrogate gene expression in Saccharomyces cerevisiae. Methods 2002, 26:281-290.

35. Lim FL, Hayes A, West AG, Pic-Taylor A, Darieva Z, Morgan BA, Oliver SG, Sharrocks AD: Mcm1p-induced DNA bending regulates the formation of ternary transcription factor complexes. Mol Cell Biol 2003, 23:450-461.

36. Arvas M, Pakula T, Lanthaler K, Saloheimo M, Valkonen M, Suortti T, Robson $\mathrm{G}$, Penttilä M: Common features and interesting differences in transcriptional responses to secretion stress in the fungi Trichoderma reesei and Saccharomyces cerevisiae. BMC Genomics 2006, 7:32.

37. Lieb JD, Liu X, Botstein D, Brown PO: Promoter-specific binding of Rap1 revealed by genome-wide maps of protein-DNA association. Nat Genet 2001, 28:327-334.

38. Denis $\mathrm{CL}$, Young ET: Isolation and characterization of the positive regulatory gene ADR1 from Saccharomyces cerevisiae. Mol Cell Biol 1983, 3:360-370.

39. Liko D, Slattery MG, Heideman W: Stb3 binds to ribosomal RNA processing element motifs that control transcriptional responses to growth in S. cerevisiae. J Biol Chem 2007, 282:26623-26628.

40. Gasch AP, Spellman PT, Kao CM, Carmel-Harel O, Eisen MB, Storz G, Botstein D, Brown PO: Genomic expression programs in the response of yeast cells to environmental changes. Moll Bio/ Cell 2000, 11:4241-4257.

41. Kim W, Spear ED, Ng DT: Yos9p detects and targets misfolded glycoproteins for ER-associated degradation. Mol Cell 2005, 19:753-764.

42. Robb A, Brown JD: Protein transport: two translocons are better than one. Mol Cell 2001, 8:484-486.

43. Nevalainen $\mathrm{H}$, Peterson $\mathrm{R}$ : Making recombinant proteins in filamentous fungi- are we expecting too much? Front Microbiol 2014, 5:75.

44. Lee S, Wormsley S, Kamoun S, Lee A, Joiner K, Wong B: An analysis of the Candida albicans genome database for soluble secreted proteins using computer-based prediction algorithms. Yeast 2003, 20:595-610.

45. Swaim C, Anton B, Sharma S, Taron C, Benner J: Physical and computational analysis of the yeast Kluyveromyces lactis secreted proteome. Proteomics 2008, 8:2714-2723.

46. Brustolini OJB, Fietto LG, Cruz CD, Passos FML: Computational analysis of the interaction between transcription factors and the predicted secreted proteome of the yeast Kluyveromyces lactis. BMC Bioinformatics 2009, 10:194.

47. Mattanovich D, Graf A, Stadlmann J, Dragosits M, Redl A, Maurer M, Kleinheinz M, Sauer M, Altmann F, Gasser B: Genome, secretome and glucose transport highlight unique features of the protein production host Pichia pastoris. Microb Cell Fact 2009, 8:29.

48. Tsang A, Butler G, Powlowski J, Panisko EA, Baker SE: Analytical and computational approaches to define the Aspergillus niger secretome. Fungal Genet Biol 2009, 46:S153-S160. 
49. Druzhinina I, Shelest E, Kubicek CP: Novel traits of Trichoderma predicted through the analysis of its secretome. FEMS Microbiol Lett 2012, 337:1-9.

50. Rodrigues ML, Franzen AJ, Nimrichter L, Miranda K: Vesicular mechanisms of traffic of fungal molecules to the extracellular space. Curr Opin Microbiol 2013, 16:414-420.

51. Pridham TG, Raper KB: Ashbya gossypii - Its significance in nature and in the laboratory. Mycologia 1950, 42:603-623.

52. Ribeiro O, Domingues L, Penttilä M, Wiebe MG: Nutritional requirements and strain heterogeneity in Ashbya gossypii. J Basic Microbiol 2012 52:582-589.

53. Stahmann KP, Böddecker T, Sahm H: Regulation and properties of a fungal lipase showing interfacial inactivation by gas bubbles, or droplets of lipid or fatty acid. Eur J Biochem 1997, 244:220-225.

54. Ribeiro O, Magalhães F, Aguiar TQ, Wiebe MG, Penttilä M, Domingues L: Random and direct mutagenesis to enhance protein secretion in Ashbya gossypii. Bioengineered 2013, 4:322-331.

55. Rawlings ND, Barrett AJ, Bateman A: MEROPS: the database of proteolytic enzymes, their substrates and inhibitors. Nucleic Acids Res 2012, 40:D343-D350.

56. Aguiar TQ, Dinis C, Magalhães F, Oliveira C, Wiebe MG, Penttilä M, Domingues $\mathrm{L}$ : Molecular and functional characterization of an invertase secreted by Ashbya gossypii. Mol Biotechnol 2014, 56:524-534.

57. Steiner S, Philippsen P: Sequence and promoter analysis of the highly expressed TEF gene of the filamentous fungus Ashbya gossypii. Mol Gen Genet 1994, 242:263-271.

58. Magalhães F, Aguiar TQ, Oliveira C, Domingues L: High-level expression of Aspergillus niger $\beta$-galactosidase in Ashbya gossypii. Biotechnol Prog 2014 30:261-268.

59. Guillemette T, van Peij NN, Goosen T, Lanthaler K, Robson GD, van den Hondel CA, Stam H, Archer DB: Genomic analysis of the secretion stress response in the enzymeproducing cell factory Aspergillus niger. BMC Genomics 2007, 8:158.

60. Carvalho ND, Arentshorst M, Kooistra R, Stam H, Sagt CM, van den Hondel CA, Ram AF: Effects of a defective ERAD pathway on growth and heterologous protein production in Aspergillus niger. Appl Microbiol Biotechnol 2011, 89:357-373.

61. Saloheimo M, Valkonen M, Penttilä M: Activation mechanisms of the $\mathrm{HACl}$-mediated unfolded protein response in filamentous fungi. Mol Microbiol 2003, 47:1149-1161.

62. Graf A, Gasser B, Dragosits M, Sauer M, Leparc GG, Tuchler T, Kreil DP, Mattanovich D: Novel insights into the unfolded protein response using Pichia pastoris specific DNA microarrays. BMC Genomics 2008, 9:390.

63. Wimalasena TT, Enjalbert B, Guillemette T, Plumridge A, Budge S, Yin Z Brown AJP, Archer DB: Impact of the unfolded protein response upon genome-wide expression patterns, and the role of Hac1 in the polarized growth, of Candida albicans. Fungal Genet Biol 2008, 45:1235-1247.

64. Schröder M, Clark R, Kaufman RJ: IRE1- and HAC1-independent transcriptional regulation in the unfolded protein response of yeast. Mol Microbiol 2003, 49:591-606

65. Pakula TM, Laxell M, Huuskonen A, Uusitalo J, Saloheimo M, Penttilä M: The effects of drugs inhibiting protein secretion in the filamentous fungus Trichoderma reesei. Evidence for down-regulation of genes that encode secreted proteins in the stressed cells. J Biol Chem 2003, 278:45011-45020.

66. Al-Sheikh H, Watson AJ, Lacey GA, Punt PJ, MacKenzie DA, Jeenes DJ, Pakula T, Penttilä M, Alcocer MJC, Archer DB: Endoplasmic reticulum stress leads to the selective transcriptional downregulation of the glucoamylase gene in Aspergillus niger. Mol Microbiol 2004, 53:1731-1742.

67. Kimata Y, Ishiwata-Kimata Y, Yamada S, Kohno K: Yeast unfolded protein response pathway regulates expression of genes for anti-oxidative stress and for cell surface proteins. Genes Cells 2006, 11:59-69.

68. Metzger MB, Michaelis S: Analysis of quality control substrates in distinct cellular compartments reveals a unique role for Rpn4p in tolerating misfolded membrane proteins. Mol Biol Cell 2009, 20:1006-1019.

69. Geiler-Samerotte KA, Dion MF, Budnik BA, Wang SM, Hartl DL, Drummond DA: Misfolded proteins impose a dosage-dependent fitness cost and trigger a cytosolic unfolded protein response in yeast. Proc Natl Acad SCi U S A 2011, 108:680-685.

70. Caramelo JJ, Parodi AJ: Getting in and out from calnexin/calreticulin cycles. J Biol Chem 2008, 283:10221-10225.
71. Xu X, Kanbara K, Azakami H, Kato A: Expression and characterization of Saccharomyces cerevisiae Cne1p, a calnexin homologue. J Biochem 2004 135:615-618.

72. Arvan P, Zhao X, Ramos-Castaneda J, Chang A: Secretory pathway quality control operating in golgi, plasmalemmal, and endosomal systems. Traffic 2002, 3:771-780.

73. Brachat S, Dietrich FS, Voegeli S, Zhang Z, Stuart L, Lerch A, Gates K, Gaffney T, Philippsen P: Reinvestigation of the Saccharomyces cerevisiae genome annotation by comparison to the genome of a related fungus: Ashbya gossypii. Genome Biol 2003, 4:R45.

74. Nikolaou E, Agrafioti I, Stumpf M, Quinn J, Stansfield I, Brown AJP: Phylogenetic diversity of stress signalling pathways in fungi. BMC Evol Biol 2009, 9:44.

75. Wu X, Chi X, Wang P, Zheng D, Ding R, Li Y: The evolutionary rate variation among genes of HOG-signaling pathway in yeast genomes. Biol Direct 2010, 5:46.

76. Verduyn C, Postma E, Scheffers WA, Van Dijken JP: Effect of benzoic acid on metabolic fluxes in yeasts: A continuous-culture study on the regulation of respiration and alcoholic fermentation. Yeast 1992, 8:501-517

77. Wiebe MG, Robson GD, Shuster J, Trinci AP: Evolution of a recombinant (gucoamylase-producing) strain of Fusarium venenatum $\mathrm{A} 3 / 5$ in chemostat culture. Biotechnol Bioeng 2001, 73:146-156.

78. Toivari MH, Ruohonen L, Richard P, Penttilä M, Wiebe MG: Saccharomyces cerevisiae engineered to produce D-xylonate. Appl Microbiol Biotechnol 2010, 88:751-760.

79. Bendtsen JD, Nielsen H, von Heijne G, Brunak S: Improved prediction of signal peptides: SignalP 3.0. J Mol Biol 2004, 340:783-795.

80. Krogh A, Larsson B, von Heijne G, Sonnhammer EL: Predicting transmembrane protein topology with a hidden Markov model: application to complete genomes. J Mol Biol 2001, 305:567-580.

81. Eisenhaber B, Schneider G, Wildpaner M, Eisenhaber F: A sensitive predicto for potential GPI lipid modification sites in fungal protein sequences and its application to genome-wide studies for Aspergillus nidulans, Candida albicans, Neurospora crassa, Saccharomyces cerevisiae and Schizosaccharomyces pombe. J Mol Biol 2004, 337:243-253.

82. Consortium UP: Update on activities at the Universal Protein Resource (UniProt) in 2013. Nucleic Acids Res 2013, 41:D43-D47.

83. Cantarel BL, Coutinho PM, Rancurel C, Bernard T, Lombard V, Henrissat B: The Carbohydrate-Active EnZymes database (CAZy): an expert resource for glycogenomics. Nucleic Acids Res 2009, 37:D233-D238.

84. Rice P, Longden I, Bleasby A: EMBOSS: The European Molecular Biology Open Software Suite. Trends Genet 2000, 16:276-277.

85. Aguiar TQ, Dinis C, Domingues L: Cre-loxP-based system for removal and reuse of selection markers in Ashbya gossypii targeted engineering. Fungal Genet Biol 2014, 68:1-8.

86. Irizarry RA, Bolstad BM, Collin F, Cope LM, Hobbs B, Speed TP: Summaries of Affymetrix GeneChip probe level data. Nucleic Acids Res 2003 31:e15

87. Kauffmann A, Gentleman R, Huber W: arrayQualityMetrics - a bioconductor package for quality assessment of microarray data. Bioinformatics 2009, 25:415-416

88. Smyth GK: Linear models and empirical bayes methods for assessing differential expression in microarray experiments. Stat Appl Genet Mol Biol 2004, 3:Article3.

89. Storey J, Taylor JE, Siegmund D: Strong control, conservative point estimation and simultaneous conservative consistency of false discovery rates: a unified approach. J R Statist Soc B 2004, 66:187-205

90. Futschik ME, Carlisle B: Noise-robust soft clustering of gene expression time-course data. J Bioinform Comput Biol 2005, 3:965-988.

91. Gattiker A, Rischatsch R, Demougin P, Voegeli S, Dietrich FS, Philippsen P, Primig M: Ashbya Genome Database 3.0: a cross-species genome and transcriptome browser for yeast biologists. BMC Genomics 2007 8:9.

92. Efron B, Tibshirani $\mathrm{R}$ : On testing the significance of sets of genes. Ann Appl Stat 2007, 1:107-129.

93. Falcon S, Gentleman R: Using GOstats to test gene lists for GO term association. Bioinformatics 2007, 23:257-258.

94. Supek F, Bošnjak M, Škunca N, Šmuc T: REVIGO summarizes and visualizes long lists of gene ontology terms. PLoS One 2011, 6:e21800. 
95. Elemento O, Slonim N, Tavazoie S: A universal framework for regulatory element discovery across all genomes and data types. Mol Cell 2007, 28:337-350.

96. Gasch AP, Moses AM, Chiang DY, Fraser HB, Berardini M, Eisen MB: Conservation and evolution of cis-regulatory systems in ascomycete fungi. PLOS Biol 2004, 2:e398.

doi:10.1186/1471-2164-15-1137

Cite this article as: Aguiar et al.: Investigation of protein secretion and secretion stress in Ashbya gossypii. BMC Genomics 2014 15:1137.

\section{Submit your next manuscript to BioMed Central} and take full advantage of:

- Convenient online submission

- Thorough peer review

- No space constraints or color figure charges

- Immediate publication on acceptance

- Inclusion in PubMed, CAS, Scopus and Google Scholar

- Research which is freely available for redistribution 